\title{
Apply of Textmining Method to Study the Roles in Improving the Health by Lactoferrin, a Multi-Functional Milk Protein
}

Kei-ichi SHIMAZAKI ${ }^{1}$, Tatsuya KUSHIDA ${ }^{2}$, Koji YAMAUCHI ${ }^{3}$ and Toshihisa TAKAGI ${ }^{4}$

${ }^{1}$ Hokkaido University, Sapporo, ${ }^{2}$ NalaPro Technologies, Inc., Tokyo

${ }^{3}$ Food Science \& Technology Institute, Morinage Milk Co., Ltd., Zama

${ }^{4}$ Database Center for Life Science, ROIS, Tokyo

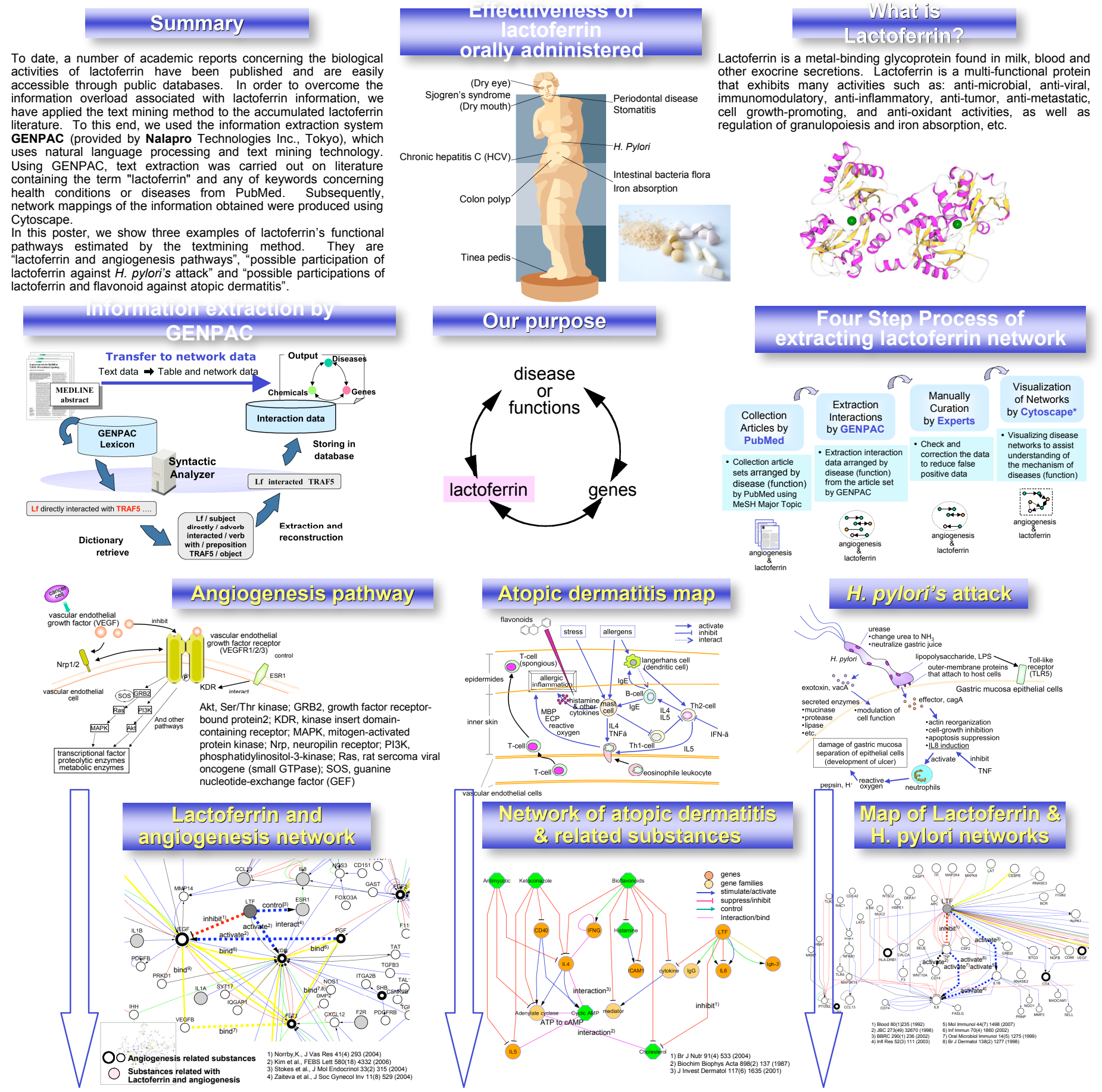

Possible partjcjpatjon maps of lactoferrin agajnst angjogenesis, atopjc dermatitis \& $H_{\text {. }}$ py/orj
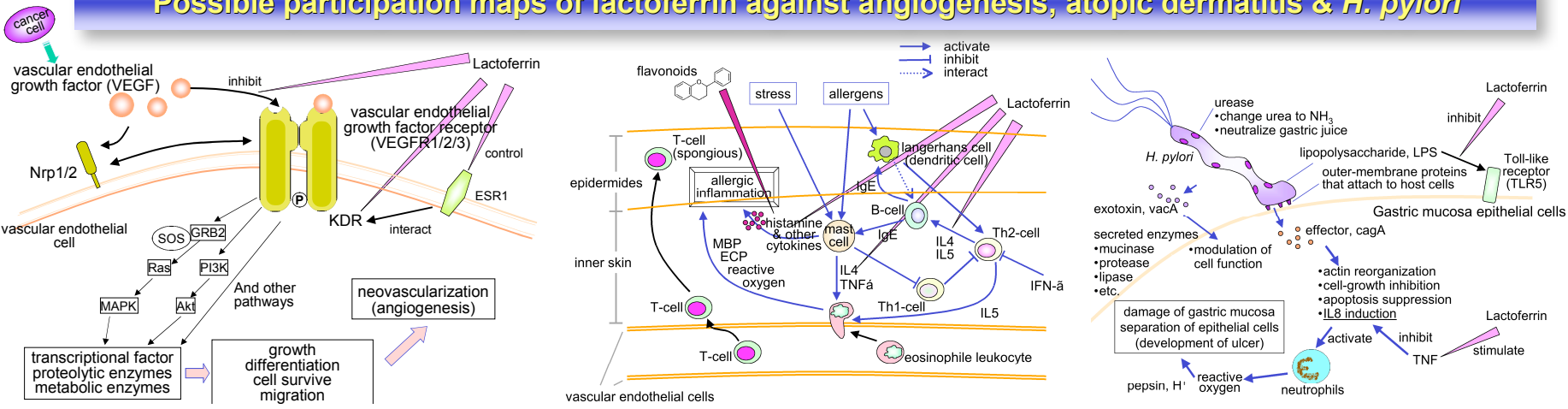